\title{
Imagens de violência : construções e representações*
}

\author{
Tânia Siqueira Montoro**
}

\begin{abstract}
Resumo
Este trabalho propõe analisar as estratégias de construção e representação da violência no espaço sociomediático e comunicativo da televisão e do cinema no país, especialmente nas últimas décadas. Identifica como elementos estéticos e éticos agregados na linguagem audiovisual interpelam o receptor pela intensidade e imediatismo, e comungam de uma estética que, longe de optar por uma descrição objetiva e fiel da dinâmica da violência em suas manifestações na realidade social, apresenta-se como um lugar privilegiado de construção de valores, identidades, mediações e sentidos.

Palavras-chave: mídia, violência e representação.
\end{abstract}

\section{Retratos de um Brasil}

O aumento da criminalidade no Brasil possibilitou que um leque de imagens de violência ganhasse espaço, de maneira generalizada, no horário nobre na TV, em programas de gênero "popularescos", orientados pelo relato do mundo do crime, do cotidiano dos policiais. Essas imagens registram e dotam de visibilidade a dinâmica cruel da violência e da impunidade em muitas cidades do país. O cinema brasileiro também recorreu a imagens de violência para retratar o cotidiano de moradores das favelas, dos cortiços, e desvendar o dia-a-dia do comércio de armas e drogas nos bolsões de pobreza que se alastram por todo país.

* Texto apresentado no GT Culturas das Mídias - Campos - 2003.

** Doutora em Comunicação Audiovisual e Publicidade pela Universidad Autônoma de Barcelona. Professora do mestrado e doutorado da Faculdade de Comunicação da Universidade de Brasília - UnB. Pesquisadora do CNPq.

Comun. Inf., v. 5, n. 1/2, p.51-62, jan./dez. 2002 
De um modo geral, pode-se dizer que o aumento da violência foi acompanhado, nesta década, não somente pela ênfase na cobertura de seus episódios, mas também por um intenso debate sobre o excesso da sua tematização. Esta edificou um determinado imaginário que passou a informare produzir atitudes sociais referenciadas à violência.

No centro desse debate de mobilização nacional sobre o tema estão as cenas de uma violência real e cotidiana transmitidas nos telejornais, violência que emerge de forma difusa e desordenada e à qual estão sujeitos, especialmente, os habitantes das metrópoles.

Tomadas pelo ângulo do impacto da mobilização, as imagens de violência serviram também para inserir na mídia novos atores sociais. Das chacinas do Carandiru e de Eldorado do Carajás à transmissão simultânea do assalto com morte de vítimas inocentes no ônibus 174, no Rio de Janeiro, passando pelo seqüestro do apresentador Silvio Santos, chegando à rebelião em presídios com uso de telefone celular, mais do que meras imagens expostas ao voyeurismo popular, essas narrativas de violência ganham relevo e emergem como fatos de interesse, por exporem publicamente práticas de violência que, de alguma forma, deram visibilidade a conflitos, marcadamente sociais, até então envoltos na pretensa crença na cordialidade "pacífica do brasileiro"e no falso mito da democracia racial. Nessas imagens, densas e particulares, que passam a ficar cunhadas num imaginário coletivo, ganham relevo atores como crianças e adolescentes, os sem-terra, os semteto, os famintos que saqueiam lojas e supermercados, os presidiários e as condições subhumanas a que estão submetidos, a prepotência e o abuso de poder da polícia e, em casos limites, da própria justiça.

Tais imagens apontam para a existência social de um Brasil com abismal desigualdade, fruto de uma das mais perversas concentrações de renda, aliada à corrupção nas instituições policiais, ao abuso de poder de autoridades, à ineficiência da justiça e a toda ordem de desmandos institucionais.

O repertório imagético lançado para consumo público radiografa a existência de uma sociedade sem consensos, cruel e autoritária.

Rondelli (1999:147) ${ }^{1}$ substantiva a questão afirmando que "os episódios desta violência cotidiana, banal e ordinária não têm inspiração e a explicação secreta e macabra dos serial killers nem a sagacidade, a inteligência ou o poder de convencimento dos personagens de ficção, nem mesmo os ideais, a determinação ou causas por que lutar, como os dos terroristas de qualquer nação ou projeto separatista. São

Comun. Inf., v. 5, n. 1/2, p.51-62, jan./dez. 2002 
atos que no modo bruto se expressam com precaríssimas mediações institucionais, revelando não só o isolamento dos setores sociais neles envolvidos, como também a impotência da sociedade em resolver seus conflitos".

Para produzir essa espiral de violência televisual, os meios de comunicação raramente buscam a motivação marcadamente psicológica que seduz espectadores de filmes de ação, terror ou suspense. As imagens de violência em circulação e consumo, nas telas aparecem como - ato de comunicativo - de um Brasil muito distinto daquele revelado nos cartões-postais ou nas publicidades milionárias da Embratur. Essas imagens, com sua força e imediatismo produzem um outro espelho de um país que insistimos em não ver.

\section{Violência e mídia : imagens em construção}

No Brasil, o estudo da violência e sua intricada relação com os meios de comunicação não encontra a tradição que possui nos Estados Unidos e no Norte da Europa, preocupados em refletir sobre a influência dos programas de conteúdos violentos sobre o comportamento dos telespectadores. Poucos são os estudos que têm como objetivo desvendar a intricada relação entre dois entes presentes na cena social e nas experiências culturais atuais: a violência e sua representação nos produtos culturais sociomediáticos veiculados nas sociedades contemporâneas.

Gerbner (1972:29) ${ }^{2}$, em um de seus primeiros estudos sobre a relação entre violência e meios de comunicação, alertava para o problema da ressonância da violência, sublinhando que quando as experiências cotidianas dos telespectadores coincidem com as coisas de que fala o cinema, a televisão e a publicidade, surge um fenômeno comunicativo chamado de ressonância - "uma dose dupla" de vivência e representação.

Em sua maioria, as pesquisas apontam uma relação complexa entre violência mediática e violência real. Diversos pesquisadores apontam a dificuldade de afirmar o impacto que a violência representada nas telas da televisão ou do cinema exerce sobre o comportamento humano, uma vez que a sociedade está composta por diferentes segmentos sociais, indivíduos e grupos que habitam contextos pessoais, socioculturais e religiosos distintos.

Comun. Inf., v. 5, n. 1/2, p.51-62, jan./dez. 2002 
Bonilla (1995:45) $)^{3}$ sublinha que boa parte das investigações desenvolvidas nas Ciências da Comunicação sobre violência e mídia, no marco das teorias dos efeitos (comportamental) ou do funcionalismopositivista, em sua maioria, tem se esquecido de conectar a reflexão ali onde ela cobra vida, nos processos e práticas sociais mediante os quais as pessoas vivem as humilhações e exclusões cotidianas - a insegurança do cidadão/ consumidor, a perda do espaço público, o impactante desarraigamento cultural, as aceleradas transformações na família, a urbanização da existência e o confinamento no privado.

É necessário matizar a dicotomia tradicional entre os efeitos positivos ou negativos da violência mediática. Há que enraizar os meios de comunicação no terreno das mediações, assumi-los dentro da complexidade dos processos de significação e de construção de sentidos como, por exemplo, no interior dos estudos das instituições que servem de mediação entre as experiências coletivas do cotidiano e a dinâmica social da vida contemporânea.

Faz-se necessário explorar novos terrenos, não mais sobre o pantanoso alicerce de como a violência mediática impacta o comportamento e atitudes dos indivíduos e grupos, mas como uma série de fatores coligados cooperam para o clima de violência instalado nas práticas culturais e no imaginário social.

Pesquisas recentes de orientação culturalista (Potter: $1999^{4}$; Silberman e Lira 19995 ; Zilmann:19986 ) sobre o consumo de produtos culturais sociomediáticos contemporâneos demonstram que:

a) Um programa de televisão não é somente uma construção lingüística caracterizada por uma estrutura e um funcionamento interno, é também um evento que é produzido em um tempo e espaço determinado, que interpela o público que ativamente interage com esse texto, dentro de um contexto comunicativo a que pertencem o texto, o público e o autor;

b) Um produto cultural e sua exibição e transmissão não são um dispositivo que guarde em si um sentido definido e realizado. Pelo contrário, dada a particularidade do gênero ou formato programas de televisão, documentários em películas, clipes musicais, peças publicitárias - há uma confrontação de sentidos entre diferentes aspectos do contexto de emissão e do ato de recepção da mensagem;

Comun. Inf., v. 5, n. 1/2, p.51-62, jan./dez. 2002 
c) As análises indicam e identificam os diferentes usos do produto cultural na construção de "repertórios de imagens da realidade", apontando novas formas de socialização na contemporaneidade;

d) As imagens de violência ativam quadros comunicativos que conformam, confirmam ou rechaçam hierarquias sociais reconhecidas e sugerem modelos de ação (as possibilidades mobilizadoras das notícias);

e) As imagens de violência conferem visibilidade a novos atores sociais, destacam e classificam lugares e grupos, interagindo com a diversidade da audiência;

f) Os meios de comunicação exercem papel crucial na construção de sentidos, à medida que integram as relações sociais e as experiências culturais vivenciadas pelas sociedades contemporâneas. Na representação audiovisual, a violência é uma linguagem dotada de uma estética própria;

g) As imagens de violência, por seu imediatismo intensidade e onipresença, colocam em visibilidade outros eixos da divisão social, que não se esgotam em classes sociais, mas que se cruzam nos processos de exclusão das sociedades contemporâneas (etnia, gênero, raça, religião, formas de inserção na economia globalizada, modelos de comunicação entre excluídos e incluídos do consumo, faixa etária e outros).

García e Ramos (1998:46) ${ }^{7}$ sublinham a necessidade de que os estudos sobre violência e meios de comunicação agreguem uma série de fatores que constituem a complexidade de sua dinâmica e comecem a pensar como a mente, o sistema de representação social, o imaginário coletivo e a memória, ordenam, codificam e (re) elaboram esse conjunto discursivo de fragmentos audiovisuais, dotando-o de funções e sentidos.

Para uma análise mais fecunda é fundamental compreender o contexto discursivo no qual essas imagens são construídas para representar, observando como o ritmo acelerado da vida nos centros urbanos, a condenação do homem médio ao anonimato, o vazio de valores comuns que dêem sentido à vida, a insegurança do cidadão comum e o problema da escassez que explica a injustiça social encontram-se embricados no processo de representação.

Imbert (1992:15) ${ }^{8}$ dialoga com a temática sublinhando que existe uma violência representada, que consiste na violência tal como a re-

Comun. Inf., v. 5, n. 1/2, p.51-62, jan./dez. 2002 
presentam os meios de comunicação em seus discursos tanto referenciais (a informação) como criativos (obras de ficção, publicidade, jogos eletrónicos). Conclama os pesquisadores de Comunicação para compreender essa nova estratégia da linguagem audiovisual que disponibiliza elementos técnicos, estéticos e éticos para produzir múltiplas representações nos produtos culturais audiovisuais da contemporaneidade.

\section{Violência e representação: o X da questão}

Tão presente na história da humanidade, tão cotidiana e ao mesmo tempo tão complexa e ambígua, a violência, como conceito, apresenta muitas definições teóricas nos estudos e análises do campo da comunicação. De acordo com a etimologia latina, a palavra violência serve para uma primeira aproximação com o conceito. "Violência" advém do latim "vis", que além de vigor, potência, designa também o emprego da força, o emprego das armas, enfim, a essência autodestrutiva do homem.

Dadoun (1998:10) ${ }^{9}$ chama a atenção para o fato de que "vis" marca também o caráter essencial de um ser - o que solidifica a associação da violência à essência do homem. Em um mergulho nas histórias da trajetória humana encontramos uma imensidade de imagens de violência que fomentam nosso imaginário, desde os escritos bíblicos até as representações artísticas e do pensamento do homem.

Michault (1980:8) ${ }^{10}$ já chamava a atenção para a relação entre violência e sua representação. A situação é, pois, de imediato, tão clara como inexplicável: de um lado, a violência é totalmente real e de outro, aparece unicamente em determinado tipo de representação do campo social. Possui uma positividade inelutável e, ao mesmo tempo, flutua e se metamorfoseia conforme as convicções que a apreendem. Existe a violência e também a "violência da violência". "É uma situação de circulo [...] a violência é a guerra, a tortura, o homicídio, o extermínio. Neste sentido, a violência existe desde o ponto de vista de cada qual, perceptível em formas próprias e suaves e portadora dos condicionamentos mais refinados".

$\mathrm{O}$ autor afirma que a positividade da violência muda de aspecto segundo quem fala por ela, quem a avalia, quem a interpreta e quem a sofre. Os torturadores metamorfoseiam sua violência em "dever de Estado"; a polícia não pratica a violência, mas faz "reinar a ordem nas

Comun. Inf., v. 5, n. 1/2, p.51-62, jan./dez. 2002 
ruas"; os tiranos, quando cometem violência, dizem defender "o direito natural do seu poderio", além das violações em nome da "segurança do Estado".

A realidade da violência flutua segundo o que se percebe se quer perceber ou o que pode ser percebido como tal; acaba por haver tantas violências como critérios para utilizá-la. A violência se confunde com suas representações, se dissolve com os que a ocultam, adota as cores daqueles que a maquilam e recebe o nome dos que a justificam.

Os meios de comunicação atuam como construtores privilegiados de representações sociais e especificamente de representações sobre o crime, a violência e sobre aquelas pessoas envolvidas em suas práticas e coibições. Essas representações se realizam por meio de significados que não somente nominam a prática social, mas, a partir desse nominamento, passam a organizá-la.

A interpretação dos produtos da mídia nos remete às relações de poder, uma vez que são produtos de conflitos travados não somente no campo econômico, mas também no campo simbólico. No dizer de Martín-Barbero (1997:284) ${ }^{11}$, "é nesse terreno que se articulam as interpelações a partir das quais os sujeitos e as identidades coletivas se constituem".

No projeto integrado de pesquisa ${ }^{12}$, analisando reportagens jornalísticas e filmes do cinema brasileiro com temáticas de violência da última década, identificamos nas narrativas audiovisuais elementos comuns com relação à visibilidade da violência e suas formas de representação no espaço mediático.

Essas novas construções estéticas, ancoradas na dinamicidade da linguagem audiovisual, interpelam o receptor pela intensidade e imediatismo e comungam de uma estética, que, longe de optar por uma descrição objetiva e fiel da dinâmica da violência em sua(s) manifestação(s) na realidade social, se apresenta como um lugar privilegiado de construção de valores, identidades, mediações e sentidos.

\section{Câmera na mão - violência no telão}

Espelho e produtora do social, a televisão tem sido atacada por diferentes segmentos da sociedade por transmitir com frequiência imagens de excessiva violência, colaborando para promover a deteriorizaçao dos valores éticos e morais do tecido social. Recentemente, um movimento organizado em rede nacional, denominado

Comun. Inf., v. 5, n. 1/2, p.51-62, jan./dez. 2002 
"Quem financia esta droga de TV", vem questionando o papel da televisão na sociedade brasileira, indicando, particularmente, o aumento de conteúdos ligados à violência. A idéia do movimento é sensibilizar os anunciantes quanto aos impactos negativos dessa modalidade de programação em horários nobres da televisão brasileira.

Para Bentes (1994: 100) $)^{13}$, "se o cinema foi para os anos 60, o lugar mítico de uma modernidade revolucionária e utópica, sinônimo e possibilidade de intervenção política e de experimentação estética para toda uma geração, a televisão é, hoje, essa espécie de esgoto público das imagens, onde emergem, entretanto, cenas reveladoras do cotidiano e do imaginário do brasileiro".

No plano da arquitetura audiovisual, os produtos culturais da televisão (especialmente os jornalísticos e os dedicados à temática) e do cinema (tomamos para análise filmes como Cidade de Deus ${ }^{14}$, Madame Satã ${ }^{15}$ e O Invasor ${ }^{16}$ ) introduzem elementos estéticos utilizados na cobertura telejornalística da violência, como reportagens mediadas por angulações originais, câmeras subjetivas e uso constante do som ambiente, aportando forte fator de verossimilhança, elemento básico da tessitura dramática do espetáculo de imagens e metáforas que somente o fenômeno da violência é capaz de mobilizar.

Imagens bidimensionais com traços reflexos e som, sentidas pelo telespectador como equivalência da percepção do sujeito na circunstância da tomada: esta parece ser a equação mediante a qual se delimita o campo do visionamento, campo que foi trabalhado pelas teorias do cinema a partir da noção de identificação com a câmera. Potencialidade que é exponenciada nas transmissões ao vivo e que, na disposição fílmica narrativa da imagem-câmera, irá se expressar na exclusão do olhar para a câmera e no fechamento do espaço diegético, relegando o telespectador à posição de olhar no buraco da fechadura.

A particular inserção dessa imagem no transcorrer temporal realça o fato de tratar-se não apenas de uma imagem em movimento, mas de uma imagem móvel, tencionando o desenvolvimento da narrativa a partir da mediação da câmera, singularidade que se expressa na capacidade dessa imagem de se imiscuir no universo que é sentido como exterior ao sujeito e que interage com a própria presença que funda essa dimensão.

Na determinação das possibilidades próprias à imagem da violência, deparamos com essa estrutura central que é a dimensão referencial sobrecarregada. A sedução produzida pelo espetáculo das imagens

Comun. Inf., v. 5, n. 1/2, p.51-62, jan./dez. 2002 
de violência, com essa intensidade referencial, aliada à informação em fluxo contínuo, anula, pelo excesso, a capacidade mobilizadora que esse repertório imagético poderia exercer para alavancar a luta pela cidadania. Marcada pelo peso do tempo do fazer fabril, da imperante determinação de produzir informações, o que assistimos, na maioria das vezes, não são imagens de acontecimentos de violência, mas sua descrição em discursos imagéticos reordenados que produzem o extraordinário.

É nessa acentuação desmedida e girando em torno de si mesma, que se configura o sensacionalismo. A gravidade do extraordinário, a avidez por sua intensidade distende o cotidiano em manchete, fazendo com que seus traços múltiplos sejam enfeixados segundo a uniformidade do corte sensacionalista.

De outro lado, observa-se nessa estratégia narrativa o uso de formas de representação como motores para (reconstituir) audiovisualmente os acontecimentos de violência, tomando por empréstimo formas da ficção, com simulação de atores, infografia fixa ou animada, o recurso à serialidade discursiva e o uso abundante de efeitos especiais. Essa serialidade é a capacidade que detém um discurso de promover repetições de um tema explorado de forma recorrente com novas variantes.

Identificamos também o uso de plano seqüência (prolongado) com a finalidade de ampliar a empatia com o telespectador, recorrendo à simultaneidade com os acontecimentos encenados em frente da câmera, produzindo efeito de verdade. Homem batendo em mulher, adolescente vítima de estupro, mulher roubada pelo filho, a polícia correndo atrás de bandido, linchamento de ladrões pela população - o telespectador se sente no meio da rua, da favela, no lugar do curioso e a narrativa encaminha-se para construção de suspense.

Segundo Bentes (1994:45), "nós somos enredados num duplo espetáculo da mídia e do Estado que dramatizam a criminalidade e excitam a demanda por um endurecimento penal, desviando atenção, com o espetáculo da violência, dos problemas estruturais dos quais derivam a criminalidade, como a distribuição desigual da riqueza, marginalização e exclusão social, etc".

Diante de uma imagem parcial da violência e da criminalidade representada pela mídia, a sociedade constrói formas de resolução do problemas, por meio de paliativos que não alteram as estruturas soci-

Comun. Inf., v. 5, n. 1/2, p.51-62, jan./dez. 2002 
ais, reivindicando o aumento efetivo de policiais, de equipamentos e armas de combate ao crime. Esse espetáculo da criminalidade e sua representação na mídia infunde um caráter profundamente conservador e tecnocrático . A mídia, mediante a repetição de estereótipos sobre a criminalidade e violência, expostos numa linguagem emotiva e dramática, pede somente à sociedade civil que legitime as ações da elite política.

\section{Considerações finais}

A televisão e o cinema nos permitem confirmar que a violência, a carnificina, a crueldade estão aí se exibindo em todo seu terrível esplendor ante nossos olhos, porém, ao mesmo tempo, distante e alheia. Dessa forma, toda essa problemática, associada à representação mediática da violência, constitui um episódio de luta de ordem política que requer uma conscientização social no sentido de garantir e problematizar criticamente a qualidade da informação veiculada pelos meios de comunicação.

Almeida (2000: 103) ${ }^{17}$ afirma que o medo e a ameaça permanentes - que marcam a história de vida da população que vive em áreas de risco - sendo generalizados para a sociedade, servem à criação de um clima difuso de insegurança, que favorece a adoção de medidas repressivas e autoritárias, balizadoras do uso da força policial. Tratase, portanto, de uma lógica circular: a sociedade termina refém das estratégias de exploração do sentimento de insegurança coletiva. A violência expressa, assim, um contexto e um processo de dominação e não simplesmente ou necessariamente um conjunto de atos brutais.

A violência mediática é, assim, uma relação que produz significados, porque a ação violenta é um valor e o ato de agressão agrega valor ao ser comunicado e transferido para ser objeto de circulação e intercâmbio.

As imagens de violência e sua espetacularização geram ansiedade pública que, ao mesmo tempo, fomentam uma demanda por mais proteção policial e jurídica e maior controle da vida social. A proliferação mediática da violência garante, paradoxalmente, uma distância, um estranhamento. Daí porque os processos de mobilização contra a violência são efêmeros, pontuais, fragmentados e sua permanência na cena pública e mediática esgota-se tão logo os meios de comunicação passem a priorizar outras temáticas.

Comun. Inf., v. 5, n. 1/2, p.51-62, jan./dez. 2002 


\section{Abstract}

This work proposes to analise strategies of construction and representation of Violence within social mediatic and communicational space of the television and the cinema in this country (Brazil), particularly during the last decades. It identifies how ethical and aesthetical aggregated elements present in the audiovisual language, question the receptor through intensity and immediacy and share an aeshtetic status that, far from being an objective and true description of the dynamics of violence manifest within social reality, shows itself as a privilieged construction locus of values, identities, mediation and meanings.

Keywords: midia, violence e representation.

\section{Notas e Referências}

' RONDELLI, E. et al. Linguagens de Violência. Rio de Janeiro: Rocco, 2000. ${ }^{2}$ GERBNER , G. "Violence in television drama: Trends and symbolic functions" in Television and social behaviour: Report an content papers. Media Content and Control, Washington, D.C., v. 1. 1972.

BONILLA, J. I. Violência, Medios y Comunicación - otras pistas en la investigación. México: Ed. Trillas, 1995.

${ }^{4}$ POTTER, J. On Media Violence. Califórnia: Sage Publications, 1999.

${ }^{5}$ SILBERMAN, S.; LIRA, L.R. Medios de Comunicación y Violência. México: Ed. EFE, 1999.

ZILMANN, D. The psychology of appeal of portrayals of violence. In: GOLDSTEIN, John. (Ed.). Why we watch: the attractiveness of violent entertainment. [S.1.]: Oxford University Press, 1998.

${ }^{7}$ GARCÍA, S.; RAMOS, L. Medios de Comunicación y Violência. México: Instituto Mexicano de Psíquiatria y Fondo de Cultura Econômica, 1998.

${ }^{8}$ IMBERT, G. Los escenarios de la violência. Barcelona: Ed. Icária, 1992.

"DADOUN, R. A Violência: Ensaios acerca do "Homo violens". Rio de Janeiro: Difel, 1998.

MICHAUT, Y. Violência y Política . Barcelona: Ediciones Ruedo Ibérico, 1980.

"MARTÍN-BARBERO, J. Dos Meios às Mediações. Rio de Janeiro: Ed. UFRJ, 2001.

Coordeno o projeto integrado de pesquisa Imagens de Violência: Construções e Representações vinculado à pós-graduação da Faculdade de Comuniçação da UnB - linha Estudos da Imagem e Som.

${ }_{14}^{13}$ BENTES, I. Imagens. Campinas: Editora Unicamp, 1994.

${ }_{15}^{14}$ Filme Cidade de Deus. Diretor Fernando Meirelles e Kátia Lund, 2002.

${ }_{16}^{15}$ Filme Madame Satã. Direitor Karim Ainouz, 2002.

${ }_{17}^{16}$ Filme O invasor. Diretor Beto Brant, 2001.

ALMEIDA, S. Violência urbana e constituição de sujeitos políticos. In: . Linguagens de Violência. [S.1.: s.n.], 2000.

Comun. Inf., v. 5, n. 1/2, p.51-62, jan./dez. 2002 


\section{Referências}

MONTORO, T. Sangue na Tela: A representação da violência nos noticiários de televisão no Brasil. In: MOTTA, Luiz Gonzaga (Org.). Imprensa e Poder. Brasília: Editora UnB, 2002. p. 301-328.

MARTÍN-BARBERO, J. Procesos de comunicación y matrices de cultura: Itinerario para salir de la matriz dualista. México: FELAFACS, 1987.

PINTO, M. J. Comunicação e Discurso. São Paulo: Hacker Editores, 1999.

LIRA, M.B. "Violência y Televisión, o el discurso de la conmoción social". In: OROZCO, Guilhermo (Org.). Miradas Latino Americanas a la televisión. México: Universidad Ibero Americana, 1986. p.48-67.

NICOLS, B. Representing Reality. Bloomington: Indiana University Press, 1991.

BULCÃO, A.; MONTORO, T. "Representación Social y Publicidad: La polémica como estratégia publicitária". Comunicação e Espaço Público, Brasília, n. 3 , 1999.

PORTO, S. D. (Org.). A Incompreensão das Diferenças: 11 de setembro em Nova York. Brasília: Edições IESB, 2002.

ZUNZUNEGUI, S. Pensar la Imagen. San Sebastian: Ediciones Universidad del Pais Vasco, 2001.

Comun. Inf., v. 5, n. 1/2, p.51-62, jan./dez. 2002 